\title{
Menyusun Model yang Efisien dan Efektif dari Dimensi-Dimensi School Wellbeing untuk Memprediksi Prestasi Belajar Matematika
}

\author{
Asmadi Alsa ${ }^{1}$ \\ Aniq Hudiyah Bil Haq, Asmaul Jannah Siregar, Fitri Ayu Kusumaningrum, \\ H. Dyah Utami, Ratna Dewi Bachria
}

Fakultas Psikologi Universitas Gadjah Mada

\begin{abstract}
The study aimed to discover the combination of the variables of social relationships and means for self-fulfillment was effective for predicting students' performance in mathematics. The subjects were 83 students of $11^{\text {th }}$ grade of senior high school students in Yogyakarta. The variables were measured using the self-efficacy scale, teacher-student relationships scale, student attachment scale, parent support scale, school climate scale, and mathematics midterm exams. The data were analyzed using Stepwise regression analysis. The results indicated that out of the five independent variables, selfefficacy and teacher-student relationships were the most effective predictors. The contribution of both to mathematic performance amounted 13.3 percent, which was 6.3 percents higher if compared with self-efficacy only as single predictor. In addition, out of the five variables tested, it was the school climate did not have a significant effect on mathematic performance.
\end{abstract}

Keywords: self-efficacy, students-teacher relationships, student engagement, parental support, school climate, mathematic performance

\begin{abstract}
Abstrak. Penelitian ini bertujuan untuk menemukan kombinasi variabel variabel dalam social relationships dan means for self-fulfillment, yang efektif memprediksi prestasi belajar matematika siswa kelas 11 SMA. Subjek penelitainnya adalah 83 siswa kelas 11 SMA Negeri ' $Y$ ' di Kota Yogyakarta. Instrumen penelitian yang digunakan adalah skala efikasi diri, skala hubungan guru-siswa, skala keterikatan siswa, skala dukungan orangtua, skala iklim sekolah, dan nilai UTS Matematika. Metode analisis data yang digunakan adalah satatistik analisis regresi metode Stepwise. Hasil penelitiannya adalah bahwa dari kelima variabel independen (prediktor), kombinasi yang efektif untuk memprediksi prestasi matematika adalah variabel efikasi diri dan hubungan guru-siswa. Kontribusi keduanya terhadap prestasi matematika sebesar 13,3 persen, 6,3 persen lebih tinggi dibanding kalau hanya menggunakan variabel efikasi diri sebagai prediktor tunggal. Secara individual, dari kelima variabel independen yang diuji, hanya variabel independen iklim kelas yang korelasinya tidak signifikan dengan prestasi matematika.
\end{abstract}

Kata kunci: efikasi diri, hubungan guru-siswa, keterikatan siswa, dukungan orangtua, iklim sekolah, dan prestasi matematika

\footnotetext{
${ }^{1}$ Korespondensi mengenai isi artikel ini dapat dilakukan melalui: asmalsa@ugm.ac.id
} 
Permasalahan yang melatarbelakangi tema penelitian ini adalah permasalahan teoritik, yaitu bagaimana school wellbeing berkontribusi terhadap hasil belajar matematika siswa, bukan permasalahan empirik karena ditemukannya prestasi matematika yang rendah.

Teori humanistik menekankan pentingnya pemenuhan kebutuhan individual siswa dalam proses belajar, penerimaan atas kelebihan dan kekurangan siswa, melihat siswa apa adanya, perlakuan yang bersifat individual, yang membuat siswa menjadi nyaman dan aman dalam mengikuti pelajaran di sekolah setiap harinya. Interaksi guru-siswa serta interaksi antara siswa yang kondusif ditekankan oleh pendekatan humanistik dalam pendidikan (Eggen \& Kauchak, 1997). Semua itu akan meningkatkan motivasi belajar siswa di kelas.

Menurut pandangan humanistik, motivasi siswa bergantung pada bagaimana kontribusi sekolah bagi perkembangan siswa. Jika kelas dan pembelajaran bersifat personal dan penuh arti, maka siswa termotivasi untuk belajar, jika tidak maka siswa tidak termotivasi (Eggen \& Kauchak, 1997). Dua unsur esensial dalam proses belajar-mengajar menurut psikologi humanistik adalah; (1) bagaimana hubungan antara guru dan siswa, dan (2) seperti apakah iklim atau suasana kelas (Hamachek, dalam Eggen \& Kauchak, 1997). Guru yang penuh perhatian (care) dan bersifat mendukung (supportive), mempercayai setiap siswa, dan mempertimbangkan perkembangan personal dan keadaan emosional dalam semua perlakuan pembelajaran yang dilakukan, merupakan sikap yang harus dimiliki guru dalam pendekatan humanistik. Iklim atau suasana kelas merupakan perkembangan dari hubungan antara guru dan siswa secara kolektif. Kelas dengan pendekatan huma- nistik merupakan lingkungan yang aman dimana siswa percaya bahwa mereka dapat belajar secara baik dengan iklim yang seperti itu.

Perspektif humanistik dalam pendidikan, menurut peneliti, berkontribusi terhadap konsep school wellbeing, khususnya pada dimensi hubungan sosial (social relationships) dan sarana pemenuhan diri (means for self-fulfilment), yang menjadi fokus penelitian ini. Program school wellbeing menjadi penting diterapkan di sekolah, karena siswa yang sehat, merasa bahagia dan sejahtera dalam mengikuti pelajaran di kelas, dapat belajar secara lebih efektif dan memberi kontribusi positif pada sekolah dan lebih luas lagi pada komunitas.

School wellbeing memiliki empat dimensi, yaitu having (school conditions), loving (social relationships), being (means for self-fulfillment), dan health status (Allardt dalam Konu \& Rimpelä, 2002). Penelitian ini dibatasi pada dua dimensi yaitu loving (social relationships), dan being (means for self-fulfillment). Kedua dimensi tersebut lebih menekankan pada dimensi sosialpsikologis daripada dimensi fisik.

Berdasar dua dimensi school wellbeing yang dipilih untuk diteliti, diambil lima variabel untuk dijadikan variabel independen, yaitu; (1) iklim sekolah (school climate), (2) hubungan guru-siswa (teacher student relationships), (3) dukungan orangtua (parental support), (4) keterikatan siswa (student engagement), dan (5) efikasi diri (self efficacy). Berdasar lima variabel tersebut, penelitian ini bertujuan untuk menemukan kombinasi variabel variabel mana saja yang efektif untuk memprediksi prestasi belajar matematika siswa kelas 11 SMA. Secara teoritik hasil penelitian ini bermanfaat bagi pengembangan teori mengenai model school wellbeing yang berkontribusi terhadap prestasi matematika siswa SMA, dan secara praktis model yang 
ditemukan dapat dijadikan pedoman bagi sekolah untuk membuat skala prioritas dalam pengembangan dimensi/variabel school wellbeing agar siswa dapat mengembangkan potensi akademiknya, khususnya untuk matapelajaran matematika.

Konu dan Rimpelä (2002) mengembangkan konsep school wellbeing sebagai satu konsep tentang sekolah yang aman, nyaman, dan menyenangkan. School wellbeing merujuk pada model konseptual well-being yang dikemukakan oleh Allardt (Konu \& Rimpelä, 2002). Allardt mengemukakan bahwa dalam tradisi sosiologis, well-being juga merupakan konsep welfare yang mencakup level of living and quality of life (Konu \& Rimpelä, 2002). Selanjutnya Allardt mendefinisikan well-being sebagai keadaan yang memungkinkan individu memuaskan kebutuhan-kebutuhan dasarnya yang mencakup kebutuhan material maupun non-material (Allardt dalam Konu \& Rimpelä, 2002). Kebutuhan tersebut oleh Allardt dibagi menjadi kategori having (school conditions), loving (social relationships), dan being (means for self-fulfillment). Kemudian, dalam perkembangannya, ia menambahkan aspek health status ke dalam model school well-being (Allardt dalam Konu \& Rimpelä, 2002).

Dimensi kondisi sekolah (school conditions) tersusun dari beberapa variabel, diantaranya lingkup sekitar dan lingkungan sekolah, mata pelajaran dan organisasi, jadwal pelajaran, ukuran kelompok/kelas, hukuman, keamanan, pelayanan, pelayanan kesehatan, dan kantin. Dimensi hubungan sosial (social relationships) meliputi variabel iklim sekolah, dinamika kelompok, hubungan guru-siswa, hubungan teman sebaya, tidak ada bullying, dan hubungan sekolah dengan rumah yang kooperatif, seperti keterlibatan orangtua (parent involvement). Dimensi sarana pemenuhan diri (means for self-fulfilment) terdiri dari variabel penghargaan atas kerja siswa, kemampuan siswa untuk melakukan sesuatu atau efikasi diri, adanya dorongan atau dukungan dari pihak sekolah (dukungan guru), keterikatan siswa dalam pengambilan keputusan (student engagement), harga diri (self-esteem), dan pengembangan kreativitas. Dimensi status kesehatan (health status) berupa kesehatan mental, kesehatan fisik, dan tidak adanya gejala psikosomatis.

Dimensi social relationships dan means for self-fulfilment mencerminkan dimensi sosial-psikologis dari konsep school wellbeing. Hasil penelitian yang dilakukan Konu dan Lintonen (2006) dengan subjek siswa sekolah dasar, sekolah menengah pertama, dan sekolah menengah atas dengan jumlah sekolah sekitar 8.285 sekolah, menunjukkan bahwa interkorelasi tertinggi diantara keempat dimensi tersebut terjadi pada kedua dimensi tersebut. Koefisien korelasi yang diperoleh antara social relationship dengan means for selffulfilment sebesar 0,74 pada siswa sekolah dasar, 0,74 pada sekolah menengah pertama, dan 0,71 pada sekolah menengah atas.

Pada penelitian ini, tiga variabel dari dimensi social relationships, yaitu hubungan guru-siswa (teacher-student relationships), iklim sekolah (school climate), dukungan orangtua (parental support), dan dua variabel dari dimensi means for self-fulfilment, yaitu keterikatan siswa (student engagement) dan efikasi diri, diuji kontribusinya terhadap prestasi matematika. Prestasi matematika yang dimaksud adalah hasil belajar yang dicapai siswa setelah mengikuti proses belajar matematika dalam waktu tertentu yang berupa pengetahuan dalam konteks pelajaran matematika.

Hasil survei kesehatan di California (Hanson, dkk., 2011) menemukan bahwa siswa yang prestasi akademiknya rendah terjadi pada siswa yang memperoleh du- 
kungan sosial rendah, keterikatan dengan sekolah rendah, dan tidak terjaminnya kesehatan mereka. Terkait dengan prestasi akademik, pada siswa SMP dan SMA kelas 7, 9, dan 11, ditemukan bahwa school well-being berkorelasi positif dengan prestasi akademik.

\section{Iklim Sekolah dan Prestasi Belajar}

Menurut Loukas (2007) antara lingkungan sekolah yang satu dengan lingkungan sekolah yang lain sangatlah bervariasi. Di beberapa sekolah mungkin terasa bersahabat, menarik, dan suportif, sebaliknya di sekolah yang lain tidak bersahabat, tidak menarik, dan bahkan tidak aman. Perasaan-perasaan dan sikap yang diperoleh dari kondisi dan situasi yang ada di suatu sekolah menggambarkan iklim sekolah.

Menurut Association of Alaska School Boards' Initiative for Community Engagement (2012), iklim sekolah menunjuk pada faktor-faktor yang berkontribusi terhadap sifat dan sikap staf dan siswa di sekolah. Iklim sekolah yang positif dihubungkan dengan kelas dan lingkungan sekolah secara umum yang terkelola secara baik, harapan tinggi dan dinyatakan secara jelas mengenai tanggung jawab individual, rasa aman di sekolah, serta guru dan staf yang menghargai secara konsisten semua siswa dan secara fair merespons perilaku mereka.

Menurut National School Climate Center yang berpusat di New York, Amerika Serikat, pengertian iklim sekolah menunjuk pada kualitas dan karakter kehidupan sekolah. Iklim sekolah didasarkan pada pola-pola pengalaman siswa, orang tua, dan personil sekolah dalam kehidupan sekolah dan merefleksikan norma, tujuan, nilai, hubungan interpersonal, praktik belajar mengajar, dan struktur organisasi. Iklim sekolah yang positif meliputi: (a) norma, nilai dan harapan yang mendorong perasaan aman secara sosial, emosi, dan fisik, (b) individu dilibatkan dan dihargai, (c) siswa, orangtua, dan pendidik bekerjasama untuk mengembangkan, menghidupkan, dan berkontribusi terhadap visi sekolah, dan (d) masing-masing orang berkontribusi terhadap kegiatan dan aktivitas sekolah serta menjaga lingkungan fisik sekolah (Association of Alaska School Boards' Initiative for Community Engagement, 2012). Menurut Loukas (2007), sebagian besar peneliti sepakat bahwa pengertian iklim sekolah memiliki tiga dimensi, yaitu; (1) dimensi fisik (penampilan fisik gedung sekolah dan ruang kelas, ukuran sekolah dan rasio antara siswa dan guru, tata tertib dan organisasi kelas, ketersediaan sumber daya, aman dan nyaman); (2) dimensi sosial (kualitas hubungan interpersonal diantara siswa, guru, dan staf, perlakuan yang adil pada siswa dari guru dan staf, tingkat kompetisi dan komparasi sosial antara siswa, sampai sejauh mana siswa, guru, dan staf berkontribusi terhadap pengambilan keputusan di sekolah); dan (3) dimensi akademik (kualitas pem-belajaran, harapan guru terhadap prestasi siswa, memantau kemajuan belajar siswa dan melaporkan hasilnya kepada siswa dan orangtua).

Menurut Center for the Study and Prevention of Violance (2008) dari Institute of Behavioral Science University of Colorado Boulder, mengembangkan iklim sekolah yang sehat merupakan unsur penting bagi sekolah yang aman, yang dapat membantu perkembangan kesuksesan akademik siswa, perkembangan positif siswa, mencegah risiko, promosi kesehatan dan retensi guru. Dari tiga faktor iklim sekolah, yaitu kedisiplinan (disciplinary climate), tekanan akademik (academic press), dan keterlibatan orangtua di sekolah (parental involvement), Klinger (2000) menemukan 
bahwa faktor kedisiplinan merupakan determinan yang paling penting bagi prestasi akkademik. Menurut Ma dan Willms (dalam Klinger, 2000) beberapa penelitian menunjukkan bahwa aturan yang jelas dan masuk akal, melaksanakannya secara aktif dan sesuai, serta adanya hubungan yang positif antara siswa dengan personil sekolah, membentuk unsur dasar bagi kedisiplinan, yang kondusif untuk meningkatkan kesuksesan akademik. Bahwa iklim sekolah yang sehat membantu kesuksesan akademik, ditunjukkan oleh hasil penelitian Smith (2008) yang menemukan bahwa iklim sekolah berkorelasi positif $(r=0,462)$ dengan prestasi belajar matematika. Hasil penelitian Smith tersebut diperkuat oleh hasil penelitian Doyal (2009) yang menemukan adanya korelasi positif antara iklim sekolah dan prestasi belajar matematika baik pada siswa SD, siswa SMP, dan siswa SMA.

\section{Hubungan Guru-Siswa dan Prestasi Belajar}

Penelitian kualitatif yang dilakukan oleh Christiansen (2002) pada 80 siswa kelas 9 sampai dengan kelas 12 tentang persepsi mereka terhadap hubungan gurusiswa dan kesuksesan sekolah, menemukan bahwa mayoritas responden melaporkan bahwa sosok guru sangat penting bagi kesuksesan belajar mereka dan pengaruh hubungan tersebut berlangsung dalam jangka waktu lama. Mayoritas responden mendukung bagi perkembangan hubungan positif antara siswa dan guru. Responden mengkonfirmasi bahwa hubungan guru-siswa yang positif meningkatkan keterikatan secara aktif (active engangement) dalam proses belejar, kehadiran mengikuti pelajaran, dan membantu perkembangan ke kelas yang lebih tinggi. Membangun hubungan di dalam kelas merupakan komponen esensial bagi proses belajar-mengajar.
Bukti empirik menunjukkan bahwa hubungan guru-siswa sangat penting bagi siswa SMA. Kajian-kajian yang telah meneliti hubungan kedekatan siswa dengan guru telah menemukan bahwa siswa mengalami peningkatan secara akademik dan secara sosial dari hubungan gurusiswa yang positif (Cataldi dkk., 2009). Baker (1999) melakukan penelitian tentang perbedaan kualitas hubungan dan interaksi siswa SD kelas 3 sampai kelas 5 antara kelompok responden Amerika-Afrika yang SES-nya tinggi dan SES-nya rendah. Hasil penelitiannya menunjukkan bahwa persepsi terhadap perhatian (caring), hubungan (relationship) yang suportif dengan guru dan lingkungan sekolah yang positif, berhubungan dengan kepuasan sekolah sejak siswa berada di kelas 3. Pola interaksi yang berbeda antara siswa dan guru menghasilkan kepuasan sekolah yang juga berbeda.

Leder (1987) meneliti perbedaan pola interaksi guru-siswa pada kelompok pelajar yang berprestasi tinggi dan berprestasi rendah. Data diperoleh melalui videotaping pada siswa kelas 6 SD dalam tiga setting yang berbeda, yaitu pada matapelajaran matematika, bahasa, dan IPA. Hasil penelitian menunjukkan bahwa kualitas dan kuantitas interaksi antara guru dan siswa yang terjadi pada kelompok "best" lebih baik daripada yang terjadi pada kelompok "weakest".

Guru adalah figur yang memiliki otoritas di kelas dan karenanya memiliki peran besar bagi keberhasilan siswa di kelas. Guru yang membangun hubungan secara personal dengan semua siswanya di sekolah akan membuat siswa merasa nyaman mengikuti pelajaran dibandingkan kalau gurunya bersifat impersonal, kaku, dan banyak menghukum. Upadyaya, dkk. (2011) mengatakan bahwa guru dipandang sebagai penyebab kemungkinan 
keberhasilan atau kegagalan yang diperoleh siswanya. Hubungan guru-siswa juga menjadi penyebab motivasi dan pembentukan perilaku siswa di sekolah. Lebih lanjut Upadyaya dkk. (2011) menyebutkan beberapa penyebab kesuksesan siswa. Pendampingan yang dilakukan orangtua dan bantuan yang diberikan guru, akan menciptakan hubungan guru-siswa yang harmonis, yang mempengaruhi perilaku dan prestasi siswa di sekolah.

Pentingnya guru melakukan interaksi dengan para siswanya tanpa adanya diskriminasi akan membuat siswanya diperlakukan adil dan nyaman. Rahimpour (2011) meneliti tentang keterkaitan antara interaksi guru-siswa dan interaksi antar siswa dengan pembelajaran pada matapelajaran bahasa asing (dalam hal ini bahasa inggris). Ia melakukan penelitian dengan tema tersebut berdasar teori yang menyatakan bahwa interaksi antara guru dan siswa memfasilitasi perkembangan bahasa dan berdampak pada peningkatan penguasaan matapelajaran bahasa. Kesimpulannya, pembelajaran yang melibatkan banyak interaksi meningkatkan pemahaman bahasa. Selanjutnya, Nurwati (2009) dari hasil penelitiannya menemukan adanya hubungan positif $(r=0,266)$ yang signifikan $(p<0.05)$ antara interaksi guru-siswa dengan prestasi belajar. Peneliti lain, Gill (2012) juga menemukan adanya korelasi positif $(r=0.485)$ yang sangat signifikan $(p<0,01)$ antara hubungan guru-siswa dengan prestasi matematika. Demikian juga hasil penelitian yang dilakukan oleh Piciullo (2009) terhadap siswa kelas 9 dari tiga SMP di Long Island, New York. Hasil penelitiannya menunjukkan adanya korelasi positif antara hubungan guru-siswa dengan prestasi matematika dan prestasi bahasa inggris. Sebanyak 9 persen varian skor matematika dapat dijelaskan oleh hubungan guru-siswa dan 11 persen va- rian skor bahasa inggris dapat dijelaskan oleh hubungan guru-siswa. Hasil penelitian ini mendukung temuan bahwa hubungan yang positif antara guru dan siswa meningkatkan prestasi belajar siswa (Montalvo, Mansfield \& Miller, 2007).

\section{Dukungan Orangtua dan Prestasi Belajar}

Konsep dukungan (support) merupakan hal yang penting dalam kehidupan semua orang, khususnya bagi mereka yang yang mengalami disabilitas intelektual dan perkembangan. Schalock, dkk. (dalam Lightfoot \& LaLiberete, 2011) mendefinisikan dukungan sebagai sumber dan strategi yang bertujuan untuk mempromosikan perkembangan, pendidikan, minat, dan kesejahteraan personal dan yang meningkatkan fungsi individual. Dukungan dilihat sebagai hal penting bagi seseorang untuk berpartisipasi dalam berbagai domain kehidupan, yang meliputi peran sosial.

Menurut Larsen dan Dehle (2007) yang dimaksud dengan dukungan orangtua adalah keterikatan emosional, mental dan psikologis yang terjalin secara naluriah di antara orangtua dan anak. Dukungan orangtua terhadap anaknya akan nampak ketika anak butuh perhatian, kasih sayang, dan ketika anak menghadapi kesulitan. Schneider dan Lee (1990) menghubungkan kesuksesan akademik siswa di Asia Timur dengan nilai dan aspirasi yang mereka peroleh dari orang tuanya, dan juga pada aktivitas belajar di rumah dimana orangtua mereka terlibat dalam belajarnya. Kenyataannya semua orangtua memiliki keinginan untuk melakukan sesuatu yang terbaik bagi anak-anaknya sesuai dengan sumber-sumber yang dimiliki. Tapi seberapa besar keefektifan dukungan orangtua bergantung pada banyak alasan seperti etnis, penghasilan keluarga, 
dan lingkungan rumah serta kesadaran mereka tentang pentingnya pendidikan.

Hasil-hasil penelitian menunjukkan bahwa hakekat dukungan orangtua mengalami perubahan pada tingkat usia anak yang berbeda. Gonzalez-Pienda, dkk. (2002) menemukan bahwa dukungan orangtua menurun ketika anak melanjutkan sekolahnya dari SD ke SMP dan kemudian ke SMA. Fan (2001) dari hasil penelitiannya menemukan bahwa tanggung jawab dan performansi anak-anak berkembang lebih baik sejalan dengan perkembangan mereka menjadi lebih besar. Selanjutnya penelitian ini juga menemukan bahwa para siswa yang orangtuanya mempunyai harapan yang lebih tinggi terhadap prestasi akademik anaknya, performansi akademik siswa lebih baik dari permulaan karir akademik mereka dan mengalami percepatan dalam kemajuan akademik selama periode transisi dari SMP ke SMA. Dukungan orang tua dalam bentuk kepeduliannya dengan menyediakan waktu, mengarahkan, menyemangati anak untuk meraih sukses, dan memberi respons positif atas hasil belajar anak, akan meningkatkan prestasi akademik anak (Codjoe, 2007). Dari penelitiannya yang melibatkan beberapa variabel independen, Rothman dan Cosden (1995) menemukan bahwa persepsi terhadap kesulitan belajar, konsep diri, dan dukungan sosial (dukungan guru, orang tua, teman, dan teman kelas) berpengaruh terhadap prestasi membaca, menulis, dan matematika. Lee, dkk. (1999) dari penelitiannya terhadap siswa SMP kelas 8 di Chicago menemukan bahwa dukungan sosial dan tekanan akademik sekolah secara positif berkorelasi dengan prestasi membaca dan matematika.

Yasin dan Dzulkifli (2011) meneliti sebanyak 120 mahasiswa International Islamic University Malaysia, dan menyim- pulkan bahwa terdapat hubungan positif signifikan antara dukungan sosial dengan prestasi akademik. Cutrona, dkk. (1994) dari penelitiannya terhadap responden 418 mahasiswa menemukan korelasi yang positif antara dukungan orangtua dan indeks prestasi mahasiswa. Penelitian Chen (2005) menemukan bahwa prestasi matematika berkorelasi $(r=0,27)$ dengan dukungan guru, dan juga berkorelasi $(r=0,14)$ dengan dukungan orangtua. Chohan dan Khan (2010) meneliti dampak perhatian yang diberikan orangtua terhadap prestasi akademik dan konsep diri pada siswa sekolah dasar kelas 6. Hasilnya menunjukkan bahwa kontribusi orangtua terhadap pendidikan anak mempunyai efek konsisten dan positif terhadap prestasi akademik dan konsep diri siswa. Selanjutnya, berdasar penelitiannya berjudul Perceived Parental Support as a Predictor of Vietnamese American Academic Achievement, Linke (2010) menemukan adanya hubungan positif antara dukungan orangtua dengan prestasi akademik mahasiswa.

\section{Keterikatan Siswa dan Prestasi Belajar}

Setiap siswa yang pernah belajar di kelas pasti mengalami situasi dimana ada beberapa siswa yang lebih terikat (engaged) dalam mengikuti pelajaran di kelas daripada siswa yang lain. Siswa yang terikat dengan materi pelajaran yang diberikan akan lebih perhatian (attentive), gairah (excited), terlibat (involved), dan memiliki keinginan yang kuat untuk berpartisipasi di dalam kelas. Dari perspektif guru, dapat diduga bahwa akan ada korelasi positif yang kuat antara keterikatan siswa dengan prestasi akademiknya (Hoff \& Lopus, 2014).

Menurut The Glossary of Education Reform (2014) bahwa di dalam pendidikan, keterikatan siswa (student engagement) menunjuk pada tingkat atensi, rasa ingin 
tahu (curiosty), minat, optimisme, dan keinginan yang kuat (passion) dari siswa, yang ditunjukkan ketika mereka sedang belajar, sampai sejauh mana tingkat motivasinya saat mereka belajar dan seberapa besar kemajuan pendidikannya. Secara umum dikatakan, bahwa keterikatan siswa diprediksi atas keyakinan bahwa proses belajar meningkat ketika siswa punya rasa ingin tahu (inquisitive), berminat (interested), atau bersemangat (inspired); dan bahwa belajar cenderung jelek ketika siswa bosan (bored) dan tidak bergairah (dispassionate), atau dengan perkataan lain siswa dalam kondisi disengaged. Dalam pendidikan, istilah keterikatan siswa telah berkembang populer pada dekade belakangan ini, kemungkinan besar sebagai hasil dari pemahaman yang meningkat terhadap peran faktor-faktor intelektual, emosional, perilaku, fisik, dan sosial yang memainkan peran dalam proses belajar.

Lingkungan sekolah yang nyaman secara fisik, sosial, dan psikologis memberikan dampak positif terhadap prestasi belajar siswa. Siswa yang lebih terikat dengan tugas belajar dan tugas-tugas sekolah lainnya ternyata membawa dampak positif terhadap capaian belajarnya. Moretti (2012) menemukan adanya korelasi positif $(r=0,206)$ antara keterikatan siswa dengan prestasi akademik. Goodenow (1993) menemukan hal yang sama, bahwa terdapat korelasi positif antara keterikatan siswa dengan prestasi akademik.

Connell (1990) mengatakan bahwa siswa yang dianggap tidak terikat dengan sekolah (disengaged) memiliki prestasi akademik yang lebih buruk dibandingkan dengan kelompok siswa yang terikat (engaged) dengan sekolahnya. Penelitian Yair (2000) telah menunjukkan pentingnya keterikatan siswa dalam belajar. Siswa yang merasa peduli dengan sekolah, didukung, dan diberi kepercayaan bahwa ia akan berhasil, dan keberhasilan itu dipersepsi sebagai suatu yang penting, mampu meningkatkan prestasi akademik yang lebih tinggi. Hasil penelitian Hanson, dkk. (2011) menunjukkan bahwa prestasi akademik dapat ditingkatkan dengan adanya partisipasi siswa dan keterlibatannya pada pelayanan yang diberikan sekolah. Garcia, dkk. (2005) mengatakan bahwa keterikatan siswa yang positif di dalam kelas merupakan faktor pendorong lain yang telah dilaporkan oleh penelitian-penelitian bahwa hal tersebut meningkatkan prestasi belajar siswa.

\section{Efikasi Diri dan Prestasi Belajar}

Albert Bandura (Elliot, dkk., 1999) mendefinisikan efikasi diri sebagai penilaian individu terhadap kemampuannya untuk mengatur dan melaksanakan belajar dengan tindakan untuk meraih performansi yang direncanakan. Bandura percaya bahwa efikasi diri adalah penting untuk mengontrol motivasi siswa. Siswa yang memiliki efikasi diri kuat cenderung fokus perhatian dan usahanya terhadap tuntutan tugas dan mengurangi kesulitan-kesulitan potensial yang mungkin muncul. Parson, dkk. (2001) mengatakan bahwa efikasi diri adalah keyakinan tentang kompetensi yang dimiliki seseorang di dalam menghadapi satu situasi tertentu. Menurut Bandura (dalam Parson, dkk., 2001) efikasi diri tinggi merupakan suatu fungsi keyakinan seseorang bahwa: (a) ia mampu melakukan perilaku secara sukses yang disyaratkan untuk meraih tujuan, dan (b) perilaku itu akan membawa pada hasil yang diinginkan. Selanjutnya Bandura (2006) mengatakan bahwa efikasi diri akademik adalah keyakinan siswa dalam kemampuannya untuk berhasil dalam belajar dan menguasai tugas-tugas akademik. 
Menjaga citra diri positif merupakan motivator yang kuat bagi perilaku, termasuk perilaku belajar. Banyak perilaku manusia dimaksudkan untuk menjaga standar personal yang ia miliki. Kalau siswa yakin bahwa ia mampu berprestasi, maka ia berusaha semaksimal mungkin meraih standar personalnya itu untuk mempertahankan citra diri positif yang ia miliki. Baird, dkk. (2009) dari hasil penelitiannya menemukan bahwa siswa yang efikasi dirinya tinggi memiliki orientasi tujuan penguasaan serta memiliki prestasi akademik yang tinggi jika dibandingkan dengan siswa yang efikasi dirinya rendah yang mengadopsi orientasi tujuan penghindaran (terhadap kegagalan).

Lee dan Klien (2002) mengatakan bahwa dalam melaksanakan tugas, siswa yang efikasi dirinya tinggi akan melakukan usaha lebih banyak dan bertahan lebih lama daripada siswa yang efikasi dirinya rendah, sehingga akan nampak bahwa siswa yang efikasi dirinya tinggi lebih tekun belajar dalam menyelesaikan tugas sekalipun tugasnya menantang. Berdasar pernyataan tersebut dapat diprediksi bahwa efikasi diri berkontribusi positif terhadap hasil belajar. Hasil penelitian Tenaw (2013) terhadap 100 mahasiswa Debre Markos College of Teacher Education di Ethiopia menemukan korelasi positif $(r=0,385)$ yang sangat signifikan $(p<0,01)$ antara efikasi diri dan prestasi belajar ilmu kimia analitik. Loo dan Choy (2013) berdasar penelitiannya terhadap 178 mahasiswa politeknik tahun ketiga di Singapura menemukan sumber-sumber efikasi diri (mastery experience, vicarious experience, social persuasion, emotional arousal) berkorelasi positif dengan prestasi matematika. Shkullaku (2013) pada penelitiannya terhadap 180 mahasiswa semester pertama di European University of Tirana Albania juga menemukan adanya korelasi positif $(r=0,85)$ yang sangat signifikan antara efikasi diri dan performansi akademik. Linke (2010) meneliti 49 mahasiswa West Cost University dan 60 mahasiswa West Cost Community College, kesemuanya warga Amerika keturunan Vietnam. Hasil penelitiannya munjukkan bahwa responden yang menerima dukungan orangtua lebih tinggi memiliki efikasi diri akademik yang lebih tinggi, dan subjek yang efikasi diri akademik tinggi menunjukkan prestasi akademik yang tinggi. Tapi efikasi diri akademik tidak memediasi hubungan antara dukungan orangtua dengan prestasi akademik. Selanjutnya, penelitian yang dilakukan oleh Handayani dan Nurwidawati (2013) pada siswa kelas 8 SMP Negeri 1 Surabaya menemukan korelasi positif $(r=0,657)$ yang signifikan antara efikasi diri dan prestasi belajar.

Berdasar hasil-hasil penelitian di atas tentang keterkaitan antara variabel-variabel independen iklim sekolah, hubungan guru-siswa, dukungan orangtua, keterikatan siswa, dan efikasi diri dengan prestasi belajar, maka hipotesis penelitian yang diajukan dalam penelitian ini adalah terdapat satu kombinasi diantara variabelvariabel independen tersebut, yang efektif memprediksi prestasi belajar matematika siswa kelas 11 SMA Negeri ' $Y$ ' Yogyakarta.

\section{Metode}

Subjek penelitian adalah 83 siswa kelas 11 jurusan IPA Semester I Tahun Akademik 2013/2014 di SMA Negeri ' $Y$ ' Kota Yogyakarta. Cluster sampling digunakan untuk mengambil sampel penelitian. Dari lima kelas 11 jurusan IPA diambil tiga kelas, yaitu kelas 11 IPA-2, IPA-4, dan IPA-5. Dari 86 responden, 3 responden dinyatakan sebagai outliers secara statistik yaitu subjek nomor urut 30, 33, dan 76 . 
Subjek nomor urut 30 outlier pada variabel iklim sekolah, subjek nomor urut 33 outlier pada variabel efikasi diri, dan subjek 76 pada semua variabel independen. Suatu skor dinyatakan sebagai outlier kalau nilai $Z=3,29$ ke atas (Field, 2009).

Penelitian ini melibatkan enam variabel. Untuk mengukur lima variabel independen, yaitu hubungan guru-siswa, iklim sekolah, dukungan orangtua, efikasi diri, dan keterikatan siswa digunakan skala, sedangkan variabel prestasi belajar matematika diukur dengan menggunakan tes hasil belajar matematika.

Sebelum melakukan penelitian, peneliti menyusun skala yang akan dipakai untuk mengukur variabel-variabel penelitian. Untuk mengukur variabel hubungan guru-siswa disusun aitem-aitem dengan mengacu pada kisi-kisi yang memuat delapan dimensi dari variabel hubungan guru siswa, yaitu leadership, helping/friend$l y$, understanding, student responsibility/freedom, uncertain, dissatisfied, admonishing, dan strict. Jumlah aitem Skala Hubungan Guru-Siswa sebanyak 56 aitem, masingmasing dimensi terdiri dari 7 aitem.

Untuk mengukur variabel iklim sekolah disusun aitem-aitem dengan mengacu pada kisi-kisi yang memuat empat dimensi dari variabel iklim sekolah, yaitu institutional environment, safety, teaching and learning, dan interpersonal relationship. Jumlah aitem Skala Iklim Sekolah adalah 24 aitem, masing-masing dimensi terdiri dari 6 aitem.

Untuk mengukur variabel dukungan orangtua disusun aitem-aitem dengan mengacu pada kisi-kisi yang memuat empat aspek dari variabel dukungan orang tua, yaitu emotional, appraisal, informational, dan instrumental. Jumlah aitem Skala Dukungan Orang tua adalah sebanyak 40 aitem, yang masing-masing dimensi terdiri dari 10 aitem.
Untuk mengukur variabel keterikatan siswa disusun aitem-aitem dengan mengacu pada kisi-kisi yang memuat aspek dari variabel keterikatan siswa, yaitu cognitive, behavioral, dan emotional. Jumlah aitem Skala Keterikatan Siswa sebanyak 30 aitem.

Untuk mengukur variabel efikasi diri disusun aitem-aitem dengan mengacu pada kisi-kisi yang memuat tiga dimensi dari variabel efikasi diri, yaitu level, generality, dan strength. Jumlah aitem Skala Efikasi Diri adalah sebanyak 33 aitem, masing-masing dimensi terdiri dari 11 aitem.

Untuk mengukur prestasi matematika digunakan tes hasil belajar matematika yang dipakai pada ujian tengah semester (UTS), yang meliputi pokok bahasan "statistika" dan "teori peluang". Tes hasil belajar matematika ini dibuat oleh guru matematika kelas 11 IPA. Tes prestasi belajar (achievement test) adalah tes terstandar untuk mengukur seberapa banyak pelajar telah mempelajari konteks pelajaran yang sudah diajarkan kepadanya (Slavin, 2012).

Selanjutnya kelima skala yang sudah disusun berdasar kisi-kisinya tersebut diujicobakan untuk mengestimasi reliabilitas skala dan validitas masing-masing aitem. Pendekatan yang digunakan untuk estimasi reliabilitas semua skala adalah koefisien Alpha dari Cronbach. Untuk memvalidasi skala iklim sekolah, hubungan guru-siswa, dan efikasi diri digunakan analisis faktor, sedangkan untuk skala dukungan orangtua dan keterikatan siswa digunakan analisis rasional, yang selanjutnya menghitung koefisien korelasi aitem-total terkoreksi (corrected item total correlation) untuk mengetahui daya beda masing-masing aitem dari skala. Uji coba kelima skala dilaksanakan terhadap 59 siswa kelas 11 IPA-1 dan IPA-2 dari SMA Negeri ' $Y$ '. 
Hasil uji-coba kelima skala pengukuran menunjukkan bahwa empat skala reliabel dan satu skala kurang reliabel. Untuk menghitung daya beda setiap aitem dari skala "dukungan orangtua" dan skala "keterikatan siswa", aitem yang koefisien korelasi aitem-total terkoreksi kurang dari 0,25 tidak dimasukkan dalam skala penelitian. Untuk memvalidasi aitem dari skala iklim sekolah, hubungan guru-siswa, dan efikasi diri digunakan analisis faktor, dengan mengeluarkan aitem yang loading factor-nya kurang dari 0,5.

Skala Hubungan Guru-Siswa yang semula terdiri dari 56 aitem, setelah dilakukan uji coba, yang dapat dipakai adalah sebanyak 38 aitem. Dimensi leadership memiliki 5 aitem yang muatan faktor (loading factor)nya berkisar antara 0,526 sampai dengan 0,801, dengan koefisien Alpha $=0,730$. Dimensi helping memiliki 5 aitem yang muatan faktornya berkisar antara 0,645 sampai dengan 0,801, dengan koefisien Alpha=0,812. Dimensi understanding memiliki 6 aitem yang muatan faktornya berkisar antara 0,520 sampai dengan 0,809, dengan koefisien Alpha $=0,742$. Dimensi student responsibility memiliki 5 aitem yang muatan faktornya berkisar antara 0,581 sampai dengan 0,746, dengan koefisien Alpha=0,698. Dimensi uncertain memiliki 4 aitem yang muatan faktornya berkisar antara 0,541 sampai dengan 0,843, dengan koefisien Alpha $=0,660$. Dimensi dissatisfied memiliki 6 aitem yang muatan faktornya berkisar antara 0,618 sampai dengan 0,863, dengan koefisien Alpha= 0,845. Dimensi admonishing memiliki 4 aitem yang muatan faktornya berkisar antara 0,710 sampai dengan 0,875 , dengan koefisien Alpha=0,785. Dimensi strict memiliki 3 aitem yang muatan faktornya berkisar antara 0,702 sampai dengan 0,893 , dengan koefisien Alpha 0,718.
Skala Iklim Sekolah yang semula terdiri dari 24 aitem, setelah dilakukan uji coba yang layak dipakai adalah sebanyak 17 aitem. Dimensi instrumental environment berisi 4 aitem dengan muatan faktor masing-masing berkisar antara 0,602 sampai dengan 0,815, dengan koefisien Alpha sebesar 0,710. Dimensi safety berisi 3 aitem dengan muatan faktor masing-masing berkisar antara 0,650 sampai dengan 0,732, dengan koefisien Alpha sebesar 0,470. Dimensi teaching and learning berisi 5 aitem dengan muatan faktor masing-masing berkisar antara 0,638 sampai dengan 0,777, dengan koefisien Alpha sebesar 0,706. Dimensi interpersonal relationship berisi 5 aitem dengan muatan faktor masing-masing berkisar antara 0,506 sampai dengan 0,727, dengan koefisien Alpha sebesar 0,590

Skala Efikasi Diri yang semula terdiri dari 33 aitem, setelah dilakukan uji coba, yang layak dipakai adalah sebanyak 19 aitem. Dimensi level berisi 7 aitem dengan muatan faktor masing-masing aitem berkisar antara 0,571 sampai dengan 0,877, dengan koefisien Alpha sebesar 0,812. Dimensi generality berisi 5 aitem dengan muatan faktor masing-masing aitem berkisar antara 0,556 sampai dengan 0,793, dengan koefisien Alpha sebesar 0,762. Dimensi strength berisi 7 aitem dengan muatan faktor masing-masing aitem berkisar antara 0,567 sampai dengan 0,798, dengan koefisien Alpha sebesar 0,806.

Skala Dukungan Orangtua yang semula berjumlah 40 aitem, setelah uji coba yang dapat dipakai untuk penelitian sebanyak 34 aitem. Rentang koefisien korelasi aitem-total terkoreksi berkisar antara 0,253 sampai dengan 0,619 , dengan kefisien Alpha sebesar 0,898.

Skala Keterikatan Siswa yang semula terdiri dari 30 aitem setelah uji coba yang dapat dipakai untuk penelitian sebanyak 
22 aitem. Rentang koefisien korelasi aitemtotal terkoreksi berkisar antara 0,283 sampai dengan 0,621, dengan kefisien Alpha sebesar 0,862.

Pengambilan data variabel-variabel penelitian yang diukur dengan skala dilaksanakan sebanyak tiga kali. Seluruh siswa kelas 11 IPA-2 dan IPA-4 diminta untuk mengisi lima skala di kelasnya masing-masing. Data prestasi belajar matematika diambil dari hasil UTS. Setelah data dari keenam variabel penelitian diperoleh, selanjutnya data dideskripsikan dan dianalisis. Tabel 1 adalah penyajian data statistik dari keenam variabel penelitian, yang menyajikan statistik mean, deviasi standar $(S D)$, dan jumlah subjek.

Untuk memenuhi asumsi pemakaian statistik analisis regresi, maka dilakukan uji normalitas distribusi skor dari keenam variabel. Tabel 2 menunjukkan bahwa distribusi skor keenam variabel adalah normal.

Asumsi selanjutnya adalah linearitas hubungan antara masing-masing prediktor (variabel independen) dengan kriterium (variabel dependen) nya. Linearitas hubungan antara masing-masing prediktor dengan kriteriumnya disajikan pada Tabel 3.

Asumsi tidak terjadinya multkoliniaritas antara kelima variabel independen juga terpenuhi, nilai Variance Inflation Factor (VIF) semuanya sibawah angka 5. Secara urut nilai VIF kelima variabel independen adalah 1,087 untuk variabel hubungan guru-siswa, 0,658 untuk variabel iklim sekolah, 0,777 untuk variabel dukungan orang tua, 1,727 untuk variabel keterikatan siswa, dan 0,787 untuk variabel efikasi diri.

Tabel 1

Statistik Deskriptif Enam Variabel Penelitian

\begin{tabular}{lcrc}
\hline \multicolumn{1}{c}{ Variabel } & Mean & \multicolumn{1}{c}{$S D$} & $N$ \\
\hline Prestasi Matematika & 13,8554 & 3,82907 & 83 \\
Hubungan Guru-Siswa & $0,0304(\mathrm{Z})$ & 5,71372 & 83 \\
Iklim Sekolah & 36,4940 & 2,74341 & 83 \\
Dukungan Orangtua & 109,1566 & 10,58356 & 83 \\
Keterikatan Siswa & 64,5542 & 6,77019 & 83 \\
Efikasi Diri & $0,2288(\mathrm{Z})$ & 2,29229 & 83 \\
\hline
\end{tabular}

Catatan: Mean untuk variabel Hubungan Guru-Siswa dan Efikasi Diri menggunakan nilai standar $Z$

Tabel 2

Asumsi normalitas distribusi skor enam variabel

\begin{tabular}{lccc}
\hline \multicolumn{1}{c}{ Variabel } & $\boldsymbol{Z}_{K-s}$ & $\boldsymbol{p}$ & Status \\
\hline Prestasi Matematika & 0,979 & $>0,05$ & Normal \\
Hubungan Guru-Siswa & 1,187 & $>0,05$ & Normal \\
Iklim Sekolah & 0,772 & $>0,05$ & Normal \\
Dukungan Orangtua & 0,537 & $>0,05$ & Normal \\
Keterikatan Siswa & 1,021 & $>0,05$ & Normal \\
Efikasi Diri & 0,874 & $>0,05$ & Normal \\
\hline
\end{tabular}


Tabel 3

Linearitas hubungan antara kelima prediktor dengan kriterium

\begin{tabular}{lccccl}
\hline \multicolumn{1}{c}{ Prediktor } & $\boldsymbol{F ~}$ lin $_{\text {riswa }}$ & $\boldsymbol{p}$ & $\boldsymbol{F}$ deviasi & $\boldsymbol{p}$ & \multicolumn{1}{c}{ Status } \\
\hline Hubungan Guru-Siswa & 5,367 & 0,024 & 1,188 & 0,301 & Linier \\
Iklim Sekolah & 2,929 & 0,091 & 1,913 & 0,048 & Mendekati linier \\
Dukungan Orangtua & 5,361 & 0,025 & 1,400 & 0,114 & Linier \\
Keterikatan Siswa & 6,921 & 0,011 & 1,149 & 0,326 & Linier \\
Efikasi Diri & 5,115 & 0,064 & 0,688 & 0,794 & Linier \\
\hline
\end{tabular}

Kriterium: Prestasi Belajar Matematika

Sesuai dengan tujuan dan hipotesis penelitian, untuk menguji hipotesis penelitian digunakan statistik inferensial dengan menggunakan analisis regresi metode stepwise. Pada metode stepwiswe, prediktor pertama yang dimasukkan kedalam model adalah prediktor yang memiliki koefisien korelasi sederhana (simple correlation) tertinggi dengan variabel dependen. Jika prediktor ini secara signifikan mampu memprediksi kriterium, maka diperoleh model regresi yang pertama. Untuk menyusun model kedua, dimasukkan prediktor yang mempunyai korelasi semi parsial tertinggi (dibandingkan dengan prediktor-prediktor lain sisanya) dengan variabel dependen. Kalau tambahan prediktor ini signifikan memperkuat daya prediksi dari model, maka diperoleh model regresi kedua. Langkah selanjutnya adalah memasukkan prediktor ketiga dalam model, demikian seterusnya (Field, 2009).

Berdasar hasil analisis regresi, dengan memasukkan seluruh variabel independen secara simultan, diperoleh koefisien korelasi product moment dan koefisien korelasi semi parsial, yang hasilnya disajikan pada Tabel 4.

Berdasar Tabel 4, maka untuk menyusun model, variabel independen yang pertamakali dimasukkan dalam model adalah Efikasi diri, karena ia yang memiliki koefisien korelasi sederhana tertinggi dengan variabel dependen $(0,286)$ dibandingkan dengan variabel independen yang lain.

\section{$\mathrm{H}$ a $\mathrm{s}$ i 1}

Model 1 dengan prediktor efikasi diri terbukti efektif memprediksi prestasi belajar $(p<0,01)$ dengan kontribusi sebesar 7 persen. Selanjutnya disusun model kedua dengan memasukkan variabel hubungan guru-siswa, karena ia yang memiliki koefisien korelasi semi parsial tertinggi dengan variabel dependen $(0,217)$ dibandingkan dengan tiga variabel independen lainnya. Model kedua ini dapat meningkatkan daya prediksi model pertama secara signifikan sebesar 6,3 persen. Hasil analisisnya disajikan pada Tabel 5 .

Ketika menyusun model ketiga dengan memasukkan variabel independen dukungan orangtua, yang mempunyai koefisien korelasi semi parsial tertinggi $(0,138)$ dari dua variabel independen sisanya, ternyata tidak meningkatkan daya prediksi model. Karena penambahan variabel independen ketiga, yang notabene memiliki koefisien korelasi semi parsial tertinggi dari dua variabel independen sisanya tidak menambah daya prediksi model, proses penyusunan model dihentikan. Jadi model regresi yang efektif untuk memprediksi prestasi matematika adalah model yang mengkombinasikan dua prediktor, yaitu prediktor efikasi diri dan prediktor hubungan guru-siswa. Sum- 
Tabel 4

Koefisien korelasi sederhana dan semi parsial masing-masing variablel independen dan prestasi belajar matematika

\begin{tabular}{lcc}
\hline Variabel Independen & $\begin{array}{c}\text { Koefisien korelasi } \\
\text { product moment }\end{array}$ & $\begin{array}{c}\text { Koefisien korelasi } \\
\text { semi parsial }\end{array}$ \\
\hline Efikasi diri & $0,286^{*}$ & 0,159 \\
Keterikatan siswa & $0,275^{*}$ & 0,076 \\
Hubungan guru-siswa & $0,252^{*}$ & $0,217^{*}$ \\
Dukungan orangtua & $0,229^{*}$ & 0,138 \\
Iklim sekolah & 0,176 & $-0,005$ \\
\hline
\end{tabular}

Tabel 5

Ringkasan Model Analisis Regresi

\begin{tabular}{cccccccc}
\hline Model & $\boldsymbol{R}$ & $\boldsymbol{R}^{2}$ & $\begin{array}{c}\text { Adjusted } \\
\boldsymbol{R}^{2}\end{array}$ & $\boldsymbol{R}^{2}$ change & $\begin{array}{c}\text { Stándar } \\
\text { kesalahan }\end{array}$ & F change & $\boldsymbol{p}$ \\
\hline 1 & $0,286(\mathrm{a})$ & 0,082 & 0,070 & 0,082 & 3,692 & 7,191 & $<0,01$ \\
2 & 0,366 (b) & 0,134 & 0,133 & 0,053 & 3,606 & 4,873 & $<0,05$ \\
\hline
\end{tabular}

a Prediktor: Efikasi Diri

b Prediktor: Efikasi Diri dan Hubungan Guru-Siswa

c Variabel dependen: Prestasi Matematika

bangan kedua prediktor ini terhadap prestasi matematika sebesar 13,4 persen. Model 2 (kombinasi prediktor efikasi diri dan prediktor hubungan guru-siswa) dikatakan lebih efektif daripada model 1 (prediktor efikasi diri), karena standard error of the estimate lebih kecil $(3,606)$ dibandingkan standard error of the estimate model 1 (3,692). Hal ini juga dapat dicek melalui varian residunya, bahwa varian residu model 2 (Mean Square residu=13,010) lebih kecil dari varian residu model 1 (Mean Square residu=13,632).

Berdasar hasil analisis data ditemukan model yang efektif memprediksi prestasi matematika adalah model yang melibatkan dua prediktor, yaitu prediktor efikasi diri dan prediktor hubungan guru-siswa, dengan persamaan garis regresinya adalah: Nilai terprediksi Matematika $=0,445$ Efikasi Diri + 0,154 Hubungan Guru-Siswa $+13,794$. Besarnya kontribusi efikasi diri dan hubungan guru-siswa terhadap prestasi matematika sebesar 13,3 persen; efikasi diri menyumbang sebanyak 7 persen dan hubungan guru siswa menyumbang sebesar 6,3 persen. Secara individual melalui korelasi product moment, keempat variabel independen (Efikasi Diri, Hubungan Guru-Siswa, Dukungan Orang tua, dan Keterikatan Siswa) berkorelasi positif signifikan dengan prestasi matematika, tapi variabel independen Iklim Sekolah korelasinya tidak signifikan dengan Prestasi Belajar Matematika.

\section{Diskusi}

Kombinasi prediktor yang efektif untuk memprediksi prestasi matematika melibatkan dua variabel, yaitu efikasi diri (variabel dari dimensi means for self-fullfilment) dan variabel hubungan guru-siswa (variabel dari dimensi social relationship). Siswa yang memiliki efikasi diri tinggi yakin bahwa dirinya mampu mengikuti pelajaran, mengerjakan tugas-tugas secara baik, dan akan berprestasi tinggi. Prestasi akademik mereka tinggi disebabkan karena mereka mampu melakukan pemantau- 
an dan meregulasi diri atas dorongan yang muncul dan bersikap persisten dalam menghadapi kesulitan. Implikasi dari temuan ini bagi pendidik adalah memperhatikan efikasi diri dan regulasi usaha siswa untuk meningkatkan prestasi akademiknya (Komarraju \& Nadler, 2013). Bangunlah keyakinan pada setiap siswa bahwa ia akan mampu melakukan tugastugas sekolah dengan memberikan goalgoal yang bersifat individual dan realistis.

Untuk meningkatkan peluang agar siswa dapat sukses secara akademik, guru harus membangun hubungan personal yang suportif, penuh dengan kehangatan emosi, dan hubungan yang bermakna dengan siswa. Menurut Pianta (1999) hubungan guru-siswa yang positif dicirikan melalui komunikasi terbuka, dukungan akademik dan sosial yang eksis antara guru dan siswa. Hubungan guru-siswa menjadi penting terutama selama awal masa remaja, ketika siswa beralih dari lingkungan yang suportif, yang mereka terima ketika di sekolah dasar, ke lingkungan SMP dan SMA, yang atmosfir lingkungan suportif dan kebersamaannya berkurang.

Siswa lebih mungkin untuk mau terlibat secara emosional dan intelektual di dalam kelas ketika mereka memiliki hubungan positif dengan gurunya (Phelan, dkk., 1992). Oleh karena itu guru harus membangun hubungan positif dengan siswanya agar siswa dapat menikmati keuntungan seperti munculnya rasa senang dan meningkatnya minat siswa berada di dalam kelas, menurunkan kegaduhan atau gangguan di kelas dan meningkatkan prestasi akademik siswa (Murray, 2002). Siswa yang berprestasi tinggi akan melakukan apa yang diharapkan darinya, tapi jika hubungan gurusiswa yang kuat tidak terbentuk, mereka cenderung membuat jarak dengan guru dan dari tugas-tugas sekolah (Phelan, dkk., 1992). Jelasnya, jika guru membangun hubungan yang positif dengan siswa yang secara akademik sukses, maka siswa lebih mungkin melibatkan diri di kelas dan menginternalisasi materi pelajaran yang diberikan.

Hasil lain penelitian ini, yang menunjukkan bahwa variabel iklim sekolah korelasinya tidak signifikan dengan prestasi matematika, cukup mengejutkan. Tapi memang sejak awal, sekaligus merupakan kelemahan dari penelitian ini, diketahui bahwa skala untuk mengukur iklim sekolah memiliki koefisien reliabilitas Alpha yang rendah, khususnya untuk dua dari empat dimensi, yaitu dimensi safety $(0,470)$ dan dimensi interpersonal relationship $(0,590)$.

\section{Kepustakaan}

Association of Alaska Boards' Initiative for Community Engagement (2012). Diunduh dari: http://alaskaice.org/ school-climate/what-is/ tanggal 12 Januari 2015

Baird, G. L. Scott, W. D., Dearing, E., \& Hamill, S. K. (2009). Cognitive self regulation in youth with and without learning disabilities: Academic selfefficacy, theories of intelligence, learning vs. performance goal preference, and effort attributions. Journal of Social and Clinical Psychology, 28(7), 881-908.

Baker, J. A. (1999). Teacher-student interaction in urban at-risk classroom: Differential behavior, relationship quality, and student satisfaction with school. University of Georgia. The Elementary School Journal, The University of Chicago Press.

Bandura, A. (2006). Guide for constructing self-efficacy scale. Dalam F. Pajares \& T. Urdan (Eds). Self-efficacy beliefs of 
adolescents, 5, 307-337. Greenwich, C.T. Information Age Publishing.

Cataldi, E. F., Laird, J., \& Kewalramani, A. (2009). High school dropout and completion rates in the United States: 2007 (NCES 2009-064). Washington, DC: National Center for Education Statistics, Institute of Education Sciences, U.S. Department of EducationCenter for the Study and Prevention of Violance, Institute of Behavioral Science, University of Colorado Boulder. Diunduh dari: http://www.colorado.edu/cspv/ schoolclimate.html tanggal 12 Januari 2015.

Center for the Study and Prevention of School Violence (2008). Safe SchoolsSafe Communities: Fact Sheet. Institute of Behavioral Science. Boulder: University of Colorado

Chen, J. J. (2005). Relation of academic support from parents, teacher, and peers to Hong Kong Adolescents' Academic Achievement: The mediating role of academic engagament. Genetic, Social, and General Psychology Monographs, 13(2), 77-127. Heldref Publications.

Christiansen, J. R. (2002). Student/teacher relationships and school success: perception of student from grades nine to twelve. Requirements for the degree Master of Education.University of Alberta Diunduh dari: https:// www.uleth.ca/dspace/bitstream/han dle/10133/986/Christiansen_Jolene

_Rae.pdf?sequence $=1$ tanggal 14 Januari 2015.

Chohan, M. B. I., \& Khan, R. M. (2010). Impact of Parental Support on the Academic Performance and Self Concept of the Student. Journal of Research and Reflections in Education, 4(1), 14 -26. Diunduh dari: http://www.ue.edu.pk/ jrre, tanggal 14 Januari 2015
Codjoe, H. M. (2007). The importance of home environment and parental encouragement in the academic achievement of African-Canadian youth. Canadian Journal of Education, 30(1), 137-156.

Connell, J. P. (1990). Context, self, and action: A motivational analysis of self esteem processes across the life-span. In D. Cicchetti (Ed.), The self in transition: From infancy to childhood (pp. 6197). Chicago: University of Chicago Press

Curtona, C. E., Cole, V., Colangelo, N., Assouline, S. G., \& Russell, D. W. (1994). Perceived parental social support and academic achievement: an attachment theory perspective. Journal of Personality and Social Psychology, 66(4), 687.

Doyal, T. S. (2009). Is there a relationship between academic achievement andschool climate at the elementary, middle, or high school grade level? Dissertation. Florida Atlantic University Boca Raton,Florida. Diunduh dari: http://search.proquest.com/docview/30 4922819/8A2BF6D49C3C4853PQ/1?accountid=13771, tanggal 14 Januari 2015

Eggen, P., \& Kauchak, D. (1997). Educational Psychology, Windows onClassroom. Third edition. Upper Saddle River, New Jersey: Prentice-Hall, Inc.

Elliot, S. N., Kratochwill, T. R., Littlefield, J., \& Travers, J. F. (1999). Educational Psychology: effective teaching effective learning. Second Edition. Singapore: McGraww-Hill Book Co.

Fan, X. (2001). Parental Involvement and Students' Academic Achievement: AGrowth Modeling Analysis. The Journal of Experimental Education, 70(1), 27-61. 
Field, A. (2009). Discovering statistics using SPSS. Third edition. London: Sage Publication, Ltd.

Garcia-Reid, P., Reid, R., \& Peterson, N. A. (2005). School engagement among Latino youth in an urban middle school context: Valuing the role of social support. Education and Urban Society, 37(3), 257-275.

Gill, K. K. (2012). Associations Between Students' Perceptions of Teacher-Student Relationship Quality, Academic Achievement, And Classroom Behavior : Are They Moderated By Ethnicity, Gender, Or Socio Economic Status?. ProQues

Goodenow, C. (1993). Classroom belonging among early adolescent students relationship to motivation and achievement. The Journal of Early Adolescence, 13(1), 21-43.

Gonzalez-Pienda, J. A, Nunez, J. C., Gonzalez-Pumariega, S., Alvarez, L., Roces, C., \& Garcia, M. (2002). A Structural Equation Model of Parental Involvement, Motivational and Aptitudinal Characteristics, and Academic Achievement. The Journal of Experimental Education, 70(3), 257-287.

Handayani, F., \& Nurwidawati, D. (2013). Hubungan self efficacy dengan prestasi belajar siswa akselerasi. Character, 01(02).

Hanson, T., Austin, G., \& Zheng, H. (2011). California Healthy Kids Survei: The Achievement gap, school wellbeing, and learning supports. Diunduh dari: http: //www.childrennow.org/uploads/docu ments/bwlw2011_brief2_hanson.pdf, tanggal 12 Januari 2015.

Hoff, J., \& Lopus, J. S. (2014). Does Student Engagement Affect Student Achievement in High School Economics Classes? Diunduh dari: http://www. frbsf.org/education/events/2014/januar
y/Does-Student-Engage-ment-AffectStudent-Achievement-in-High-SchoolEconomics-Classes.pdf.

Klinger, D. A. (2000). Hierarchical linear modelling of student and school effects on academic achievement (New Brunswick School Climate Study). Canadian Journal of Education, 25(2), 41-55.

Komarraju, M., \& Nadler, D. (2013). Selfefficacy and academic achievement:

Why do implicit beliefs, goals, and effort regulation matter? Learning and Individual Differences, 25, 67-72.

Konu, A. I., Lintonen, T. P., \& Rimpelä, M. K. (2002). Factor structure of the School Well-being Model. Health Education Research, 17(6).

Konu, A. I., Lintonen, T. P. (2006) School well-being in Grades 4-12. Health Education Research, 21(5).

Konu, A. I., \& Rimpelä, M. K. (2002). Wellbeing in School A Conceptual Model. Health Promotion International, 17(1).

Larsen, D., \& Dehle, C. (2007). Rural adolescent agression and parental emotional support. Boston: Alyyn \& Bacon.

Leder G. C., (1987). Teacher-Students Interaction: ACase Study. Educational Studies in Mathematics 18(1987), 255-271. D. Reidel Publishing Company

Lee, S., \& Klien, H. J. (2002). Relationship between conscientiousness, self-efficacy, self deception and learning over time. Journal of Applied Psychology, 87(6), 1175-1182.

Lee, V. E., Smith, J. B., Perry, T. E., \& Smylie, M. A. (1999). Social support, academic press, and student achievement: A view from the middle grade in Cicago. Diunduh dari: https://ccsr. uchicago.edu/sites/default/files/public ations/p0e01.pdf, tanggal 15 Januari 2015. 
Linke, J. M. (2010). Perceived parental support as a predictor of Vietnamese American Academic Achievement. Thesis. Fullerton: Department of Psychology. California State University.

Lightfoot, E., \& LaLiberete, T. (2011). Parental support for parents with intellectual an developmental disabilities. Intellectual and Developmental Dissabilities, 49(5).

Loo, C. W., \& Choy, J. L. F. (2013). Sources of Self-Efficacy Influencing Academic Performance of Engineering Students. American Journal of Educational Research, 1(3), 86-92.

Loukas, A. (2007). High-quality school climate is advant ageous for allstudents and may be partcularly beneficial for at-risk students. Leadership Compass. 5(1), Diunduh dari: https:// www.naesp.org/resources/2/Leadershi p_Compass/2007/ LC2007v5n1a4.pdf. tanggal 12 Januari 2015.

Montalvo, G. P., Mansfield, E. A., \& Miller, R. B. (2007). Liking or disliking the teacher: Student motivation, engagement, and achievement. Evaluation and Research in Education, 20(3), 144-257.

Moretti, J. D. (2012). The Relationship Between Middle School Students Perceptions of Physical Activity, Student Engagement, And Academic Achievement Dissertation. Faculty of the Morgridge College of Education, University. of Denver. Diunduh dari: http://digitaldu. coalliance.org/fedora/repositor/codu persen3A63825/Moretti_denver_0061D _10680.pdf/master tanggal 12 Januari 2015.

Murray, C. (2002). "Supportive teacherstudent relationships: Promoting the

Social and Emotional Health of Early Adolescents with High Incidence Dis- abilities." Childhood Education, 78(5), 285-290.

National School Climate Center (2015). New York. Diunduh dari: http://www. schoolclimate. org/climate/ tanggal 16 Januari 2015.

Nurwati, A. (2009). Hubungan Antara Interaksi Sosial Siswa Dengan Prestasi Belajar Bahasa Indonesia Siswa Madrasah Ibtidaiyah Se-Kabupaten Gorontalo. Cakrawala Pendidikan, XXV3 (2).

Parsons, R. D., Hinson, S. L., \& SardoBrown, D. (2001). Educational psychology: practitioner-researcher model of teaching. Singapore: Thomson Learning Ltd.

Phelan, P., Davidson, A., Locke, H., \& Thanh, C. (19XX) "Speaking up: students' perspectives on school." Phi Delta Kappan 73(9), 695-704.

Pianta, R. C. (1999) Enhancing relationships between children and Teachers. Washington, DC: American Psychological Assn.

Rothman, H. R., \& Cosden, M. (1995). The relationship between self-perception of learning disability and achievement, self concept, and social support. Learning Disability Quarterly, 18(3), 203212. Sage Publication, Inc.

Schneider, B., \& Lee, Y. (1990). A Model for Academic Success: The School and Home Environment of East Asian Students. Anthropology \& Education Quarterly, 21(4), 358-377

Shkullaku, R. (2013). The relationship between self-efficacy and academic performance in the contex of gender among Albanian students. European Academic Research, 1(4).

Slavin, R. E. (2012). Educational psychology. Tenth edition. Englewood Cliffs, New 
Jersey: Pearson Education, Inc.

Smith, K. M. (2008). The Impact of district and school climate on student achievement. The College of William \& Mary. Proquest, UMI Dissertation Publishing.

Tenaw, Y. A. (2013). Relationship between self-efficacy, academic achievement and gender in analytical chemistry at Debre Markos College of Teacher Education. Debre Markos: AJCE

The Glossary of Education Reform (2014). Diunduh dari: http://edglossary.org/ student engagement/ tanggal 12 Januari 2015.
Upadyaya, K., Viljaranta, J., Lerkkanen, M. K. Poikkeus, A. M., \& Nurmi, J. E. (2011). Cross-lagged relation between kindergarten teachers' causal attributions and children's interest value and performance in mathematics. Social Psychology Education, 5, 3-20.

Yasin, M. A. S. M., \& Dzulkifli, M. A. (2011). The Relationship between social support and academic achievement. International Journal of Humanities and Social Science, 1(5), 277.

Yair, G. (2000). Educational battlefields in America. The tug-of-war over students engagement with instruction. Sociology of Education, 73, 247-269. 